Citation: Işıker, Y. \& Emre, İ. (2021). The impact of argumentation-based instruction on academic achievements and scientific process skills of primary school students and their attitudes towards the science course. International Journal of Scholars in Education, 4(1). 1-14. doi:10.52134/ueader.840877

\title{
The Impact of Argumentation-Based Instruction on Academic Achievements and Scientific Process Skills of Primary School Students and Their Attitudes towards the Science Course*
}

\author{
Yakub IŞIKER**, İrfan EMRE***
}

\begin{abstract}
The present study aimed to investigate the effect of argumentation-based instruction on academic achievements, scientific process skills of primary school $4^{\text {th }}$ grade students and their attitudes towards the science course. The study was designed as a quasi-experimental research, and the study group included $474^{\text {th }}$ grade students during the 2016-2017 academic year. Academic achievement test, scientific process skills test and attitudes towards science course scale were used as pre-tests and post-tests in the study to collect data. Independent groups t-test, paired groups t-test, Mann Whitney $\mathrm{U}$ test and arithmetic mean, standard deviation, frequency and percentage analysis were employed to analyze the study data, and .05 confidence interval was accepted as significant. The study findings demonstrated that argumentation-based instruction had a positive impact on academic achievements and scientific process skills of 4th grade primary school students; and the instruction led to a significant difference that favored the experimental group in attitudes towards the science course.
\end{abstract}

Anahtar Kelimeler: Academic achievement, argumentation-based instruction, attitudes towards science, scientific process skills.

\section{Argümantasyon Tabanlı Öğretimin İlkokul Öğrencilerinin Akademik Başarılarına, Bilimsel Süreç Becerilerine ve Fen Bilimlerine Yönelik Tutumlarına Etkisi}

Öz: The Bu araştırmada argümantasyon tabanlı öğretimin ilkokul 4. sınıf öğrencilerinin akademik başarılarına, bilimsel süreç becerilerine ve fen bilimleri dersine yönelik tutumlarına ilişkin etkisi araştırılmıştır. Yarı deneysel model olarak tasarlanan araştırmanın çalışma grubunu 2016-2017 eğitim ve öğretim yılında öğrenim gören 47 öğrenci oluşturmaktadır. Veri toplama aracı olarak; akademik başarı testi, bilimsel süreç becerileri testi ve fen dersine yönelik tutum testi ön test ve son testleri kullanılmıştır. Araştırmadan elde edilen verilerin analizi için bağımsız gruplar $t$ testi, eşleştirilmiş gruplar t testi, Mann Whitney U testi ile aritmetik ortalama, standart sapma, frekans ve yüzde analizleri kullanılmış ve verilerin yorumlanmasında .05 anlamlılık düzeyi kabul edilmiştir. Araştırmanın bulguları incelendiğinde, argümantasyon tabanlı öğretimin ilkokul 4. sınıf seviyesinde öğrencilerin akademik başarıları ve bilimsel süreç becerilerine olumlu etki yaptığı bununla birlikte fen dersine yönelik tutumlarına ilişkin deney grubu lehine anlamlı düzeyde fark oluşturduğu görülmektedir.

Anahtar Kelimeler: Akademik Başarı, Argümantasyon tabanlı öğrenme, bilimsel süreç becerileri, fen bilimlerine yönelik tutum.

\footnotetext{
* The present study was based on the master's thesis of the primary author and presented as a proceeding at $3^{\text {rd }}$ International Culture and Civilization Congress

** Lecturer., Mardin Artuklu University, ORCID: 0000-0003-3493-0620 ,e-mail: yakupyasir@artuklu.edu.tr

*** Associate Professor, Frrat University, ORCID: 0000-0003-0591-3397,e-mail: iemre@ firat.edu.tr
} 


\section{Introduction}

Knowledge production today is very rapid and simultaneous developments and changes in many scientific and technological fields occur due to the advances in the $21^{\text {st }}$ century (Küçükyılmaz, 2014). Based on these developments, science education has been restructured to train competent individuals (Gençoğlan, 2017). The adoption of the constructivist approach in science programs aimed to develop learning environments centered on the student where the teacher acts as a counselor (problem-based learning, collaborative learning, project-based learning, argumentation, etc.) (The Ministiry of National Education, 2013; 2018). These objectives and learning environments aimed to train science literate individuals who could employ scientific thinking methods, make conscious decisions in scientific discussion environments and support their prepositions with reasons, and analyze the arguments with a critical approach (Köseoğlu, Tümay, \& Budak, 2008). Thus, the concept of " argumentation ", which was included in the curricula for the first time, was described as an approach where students could express their ideas freely based on a rationale; defend opposing arguments to refute the arguments in verbal and written discussions (Öğreten \& Uluçınar, 2014).

Although concept of argumentation has a long history, Toulmin (1958, 1964) introduced the concept to the field of education (Gencel \& Ilıman, 2019; Yalçın Çelik, 2010;). In the book "The Uses of Argument" published in 1958, Toulmin analyzed the natural process of a debate and presented a model that reflected the netural proceedings of a discussion, and demonstrated the basic elements and links between these elements in a discussion (Erduran, Simon, \& Osborne, 2004; Kaya \& K1lıç, 2008). Toulmin's argument model included six elements: a series of interrelated arguments, data that constitutes a basis for an argument, the reasons for the association between the data and the argument, the adjuvants that strengthen the justifications, limiting elements that determine the validity of the argument, and reject the argument when it is not true (Driver Newton \& Osborne, 2000; Simon, Erduran, \& Osborne, 2006). Toulmin classified the data, claim, justification and supporters as the basic elements, and refutation and limitations as auxiliary elements (Driver Newton \& Osborne, 2000). The basic elements are required to construct the argument, while the auxiliary elements affect the persuasiveness and validity of the argument (Simon, 2008). Toulmin realized that the conventional discussion approaches were not adequate for problem solving in daily life and distanced the theory from conventional discussion approaches and focused the argument approach on retrospective reasoning (Aldağ, 2006; Puvirajah, 2007). The argumentation-based learning (ABL), a learning approach where argumentation-based activities are conducted, was based on the constructivist learning, several learning and instructional theories, scientific literacy, comprehension of the nature of science and adequate writing activities that could be discussed (Driver, Newton and Osborne, 2000). ABL is effective in learning science, since it includes learning-oriented writing activities and inquiry-based science learning through discussion (Akkuş, Günel, \& Hand, 2007). Students reconstruct and analyze scientific concepts during the discussions in ABL (Hand, Wallace, \& Yang, 2007). This discussion process includes not only verbal discussions, but also occurs when students write and read texts on a scientific topic (Keys, Hand, Prain, \& Collins, 1999). Thus, in ABL, writing activities conducted by the students are important to construct knowledge, and for comprehension and discussion (Burke, 2005).

The argumentation-based learning approach was introduced in the 2013 Science curriculum, and the number of studies on the topic has increased ever since (Ar1k, 2016; Mall1, 2019; Memiş, 2017; Özer, 2019; Tümay \& Köseoğlu, 2011; Uluay, 2012). However, a review of the literature on science education demonstrated that these studies were generally on middle and high school science courses (Hasançebi \& Günel 2013; Memiş, 2017; Uluay 2012). Since learning scientific concepts accurately in primary school would lay the groundwork for advanced science courses, studies on argumentation-based learning in primary education should 
The Impact of Argumentation-Based Instruction on Academic Achievements and Scientific Process Skills of Primary School Students and Their Attitudes Towards the Science Course

be prioritized (Osborne, 2007; Özkara, 2011). Thus, students, who could express their ideas freely, express their ideas adequately, support these ideas with various reasons and develop opposing arguments to refute other arguments, acquire scientific knowledge through collaboration with others instead of accepting ready-made knowledge, could be trained (Ministry of National Education-MoNE, 2013).

\section{The Aim of the Study}

Several studies reported that the argumentation allows students to acquire critical thinking and inquiry skills and allows students to be active in learning areas and produce solutions to problems they may encounter in daily life through group discussions (Driver Newton \& Osborne, 2000; Hand et al. 2018; Irish 2012; Küçükaydın, 2019; Osborne, 2007;). However, the analysis of the science course curricula in Turkey revealed that argumentationbased instruction has only recently introduced since 2013 (Anagün, K1lıç, Atalay, \& Yaşar, 2015; MoNE, 2013). Furthermore, it should be noted that recent studies focused on middle school, high school and university level applications, and the number of studies on primary school curricula are limited (Naylor, Keogh, \& Downing, 2007; Özkara, 2011; Zohar \& Nemet, 2002). The students require learning environments where they could actively participate in teaching-learning processes at an early age, participate in activities as a researcher and questioner in educational activities, explain their ideas with scientific reasons, and support and discuss these ideas effectively (Açıkgöz, 2002). One of the best examples of such environments is the classroom environment where the argumentation-based instruction method is adopted.

The present study aimed to investigate the impact of argumentation-based instruction on academic achievement, scientific process skills and attitudes towards the science of primary school 4th grade students based on the scope of 'Let's Learn about Matter' unit. Because, there are the limited literature on primary school level argumentation-based instruction. In addition, "Let's Learn about Matter" includes the basic concepts about the matter and it is important to be understood in advanced classes.

\section{The Problem Statement}

Within the scope of the primary school $4^{\text {th }}$ grade "Let's Learn about Matter" unit, what is the effect of argumentation-based instruction on academic achievement, scientific process skills of the students, and their attitudes towards the science course?

\section{Sub-Problems}

1. Is there a significant difference between the pretest and posttest academic achievement scores of the experimental and control groups?

2. Is there a significant difference between the pretest and posttest academic achievement scores of the control group?

3. Is there a significant difference between the pretest and posttest academic achievement scores of the experimental group?

4. Is there a significant difference between the pretest and posttest scientific process skill scores of the experimental and control groups?

5. Is there a significant difference between the pretest and posttest scientific process skill scores of the control group?

6. Is there a significant difference between the pretest and posttest scientific process skill scores of the experimental group? 
7. Is there a significant difference between the pretest and posttest attitude towards the science course scores of the experimental and control groups?

8. Is there a significant difference between the pretest and posttest attitude towards the science course scores of the control group?

9. Is there a significant difference between the pretest and posttest attitude towards the science course scores of the experimental group?

\section{Method}

\section{The Research Model and Design}

The present study was conducted with the quasi-experimental model to compare academic achievements, scientific process skills of primary school 4th grade students and their attitudes towards science course based on the "Let's Learn about Matter" unit. Quasiexperimental models, which follow real experimental models in science, are employed when the controls required by real experimental models are not available or adequate (Çepni, 2011). In quasi-experimental design, pretest and posttest are applied to both groups, but the innovative methods are only applied with the experimental group (Cresswell, 2003). The quasiexperimental method has high application validity, considering its limitations (Karasar, 1999).

In the study, one of the students group was assigned as the control group and the other as the experimental group where argumentation-based instruction. The study was an experimental research with pretest-posttest control group. Pretests were applied before the instruction and posttest were applied after the instruction to both groups. The experimental design of the study is detailed in Table 1.

Table 1.

The Experimental Design

\begin{tabular}{lccc}
\hline Group & Pretest & Instruction Method & Posttest \\
\hline Experimental & Academic Achievement Test & Scientific Discussion & Academic Achievement Test \\
& SPST & (Argumentation) & SPST \\
& Attitude Scale & Attitude Scale \\
\hline Control & Academic Achievement Test & Conventional & Academic Achievement Test \\
& SPST & Instruction & SPST \\
& Attitude Scale & Attitude Scale \\
\hline
\end{tabular}

SPST $^{*}:$ Scientific process skills test

\section{The Study Group}

The study group included 47 students attending two separate classes in a primary school in Mardin province in Turkey during the 2016-2017 academic year. The students in the experimental and control groups were assigned with the convenience sampling method based on the curricula. Thus, the first class that included 25 students ( 13 males, 12 females) was assigned as the experimental group where argumentation-based science instruction was adopted, and the second class that included 22 students (12 males, 10 females) were assigned as the control group where conventional instruction was implemented. 
The Impact of Argumentation-Based Instruction on Academic Achievements and Scientific Process Skills of Primary School Students and Their Attitudes Towards the Science Course

\section{Procedures and Data Collection}

The study was conducted in a five-week period, where there were three class hours per week, during the instruction of the "Let's Learn about Matter" unit in the primary school 4th grade science course during the 2016-2017 academic year. Elementary science education is important to prepare students to higher classes because the basic principles and concepts are taught with the subjects including "Lets Learn about Matter" given in these classes. Pre-tests were applied to both groups before the instruction and it was observed that the mean scores of the two groups were similar. After the pretests, as the classroom teachers started to instruct the unit in the control group, basic knowledge on argumentation-based learning was instructed in the control group, and the teacher initiated scientific discussions for the comprehension of argumentation-based instruction. During the instructions, argumentation was described, how to form arguments and the significance of arguments in science education, employment of worksheets developed by the author, how to form the groups for the activities were described, and the students were introduced to the argumentation-based instruction. During the instructions conducted with the experimental group, Toulmin's argumentation model was presented by the teacher and the teacher asked discussion questions to arouse the student curiosity, developing an environment for scientific discussion. Then, discussion groups were determined (paired discussion, pairs to couples, listening trios, ambassadors, role play, jigsaw technique), worksheets (table of statements, theories that compete with stories, guess-observe-explain, theories that compete with cartoons, designing experiments) developed by the author based on the argumentation method were distributed to the students, and they were asked to defend their arguments and state the evidence behind their arguments, and then they were asked to discuss why they disagreed with the with the opposing arguments, and why the arguments presented by the other group were wrong. At the end of the discussion, the students reached a consensus after the general evaluation of the discussion.

\section{Data Collection Instruments}

In the study, an academic achievement test developed by the authors based on a literature review was employed to determine the academic achievements of the control and experimental group students. The academic achievement test was developed based on the outcomes determined for "Let's Learn about Matter" in the curriculum and included 25 multiple-choice questions. The initial form of the test included 32 questions, and it was edited based on expert opinion and item analysis conducted by the same experts who included teachers and academicians, and the final test included 25 questions. The KR-20 of the achievement test applied to 101 participants was .92 . Since the item discrimination values of the $1^{\text {st }}, 4^{\text {th }}, 19^{\text {th }}$ and $24^{\text {th }}$ questions in the achievement test were below .29 , these items were reorganized.

To determine the scientific process skills of the students, 31-item "Basic Skills ScaleBSS" developed by Padilla, Cronin and Twiest (1985) and adapted to Turkish language by Aydoğdu and Karakuş (2015) was employed. The scale aimed to score observation (5), classification (5), inference (5), measurement (5), prediction (6), and communication skills (5). The reliability coefficient of the scale $(\mathrm{KR}-20)$ was .83 , and the average difficulty of the scale was .55. Furthermore, the 5-point Likert type (totally agree, partially agree, do not know, disagree, completely disagree) "Attitudes Towards Science Course Scale" developed by Geban, Ertepınar, Yılmaz, Atlan, and Şahpaz (1994) was used to measure the attitudes of the control and experimental group students towards the science course. The reliability coefficient of the scale was determined as .83 . 


\section{Data Analysis}

In the analysis of the data collected with the academic achievement test, the scientific process skills test and the attitude towards science course scale applied to the control and experimental group students as pre-test and post-test, initially, the data was tested for normal distribution. The Kolmogorov-Smirnov test and other normality tests conducted on the study data revealed that the student scores exhibited normal distribution, and independent groups ttest, paired groups t-test, frequencies and percentages were used in data analysis. However, since it was determined that the scientific process skills pretest scores did not exhibit normal distribution, the Mann Whitney $U$ test was employed for this data. The significance level of the study data was accepted as .05. Statistical analysis was conducted with the SPSS 21.0 (Statistical Package for the Social Sciences) software.

\section{Findings}

In this section, based on the study objectives, the study data were analyzed to determine the effect of argumentation-based instruction on academic achievements, scientific process skills of the students and their attitudes towards science and the study findings are presented.

The results of the independent groups t-test conducted on experimental and control group academic achievement and attitudes towards science pretest scores are presented in Table 2.

Table 2.

Independent Samples t-Test Results: The Pre-test Experimental Group and the Control Group Scores

\begin{tabular}{|c|c|c|c|c|c|c|}
\hline Group & $\mathrm{n}$ & $\overline{\mathrm{x}}$ & $\mathrm{sd}$ & $\mathrm{t}$ & $\mathrm{p}$ & $\eta 2$ \\
\hline \multicolumn{7}{|c|}{ Academic achievement } \\
\hline Control & 22 & 13,18 & 4,21 & \multirow{2}{*}{,604 } & \multirow{2}{*}{,549 } & \multirow{2}{*}{, 008} \\
\hline Experimental & 25 & 12,40 & 4,60 & & & \\
\hline \multicolumn{7}{|c|}{ Attitudes towards science } \\
\hline Control & 22 & 52,72 & 4,90 & \multirow{2}{*}{,362 } & \multirow{2}{*}{,719 } & \multirow{2}{*}{,002 } \\
\hline Experimental & 25 & 53,20 & 4,04 & & & \\
\hline
\end{tabular}

As seen in Table 2, it was concluded that there was no significant difference ( $p>.05$ ) between the experimental group and the control group pre-test academic achievement and attitude towards science scores before the application. This demonstrated that the academic achievements of both groups were similar before the application. The partial eta squared values were found to be less than .01 (small effect).

Table 3.

Mann-Whitney U Test Analysis Results: Experimental and Control Group Scientific Process Skills Pre-test Scores

\begin{tabular}{llllrll}
\hline Group & $\mathrm{n}$ & Rank mean & Rank total & $\mathrm{U}$ & $\mathrm{p}$ & $\eta 2$ \\
\hline Control & 22 & 25,36 & 558,00 & \multirow{2}{*}{245,00} & \multirow{2}{*}{, 520} & \multirow{2}{*}{.002} \\
\hline Experimental & 25 & 22,80 & 270,00 & & \\
\hline
\end{tabular}

As seen in Table 3, there was no significant difference (p>.05) between the scientific process skills pre-test scores of the experimental and the control groups before the instruction. This demonstrated that the scientific process skills of both groups were similar before the application. The partial eta squared value was found to be less than .01. 
The Impact of Argumentation-Based Instruction on Academic Achievements and Scientific Process Skills of Primary School Students and Their Attitudes Towards the Science Course

Table 4.

Independent Samples t-Test Results: Experimental Group and the Control Group Post-test Scores

\begin{tabular}{|c|c|c|c|c|c|c|}
\hline Group & $\mathrm{n}$ & $\overline{\mathrm{x}}$ & sd & $\mathrm{t}$ & $\mathrm{p}^{*}$ & $\eta 2$ \\
\hline & \multicolumn{6}{|c|}{ Academic achievement } \\
\hline Control & 22 & 15,54 & 4,38 & \multirow{2}{*}{,738 } & \multirow{2}{*}{,464 } & \multirow{2}{*}{, 01} \\
\hline Experimental & 25 & 16,68 & 5,925 & & & \\
\hline & \multicolumn{6}{|c|}{ Basic process skills test } \\
\hline Control & 22 & 14,54 & 4,52 & 1,351 & 183 & ,03 \\
\hline Experimental & 25 & 16,44 & 5,02 & & & \\
\hline \multicolumn{7}{|c|}{ Attitudes towards science } \\
\hline Control & 22 & 52,09 & 3,08 & 7,04 & ,000 & ,52 \\
\hline Experimental & 25 & 60,36 & 4,66 & & & \\
\hline
\end{tabular}

The results of the independent samples t-test conducted on the academic achievement, basic process skills and attitudes towards science pretest scores are presented in Table 4. It was found the small effect in academic achievement; the small-medium effect in basic process skill and the big effect in attitudes towards science between control and experimental groups.

Table 5.

The Control Group Paired Samples t-Test Results

\begin{tabular}{|c|c|c|c|c|c|c|}
\hline Test & $\mathrm{n}$ & $\overline{\mathrm{x}}$ & $\mathrm{sd}$ & $\mathrm{t}$ & $\mathrm{p}$ & $\eta 2$ \\
\hline \multicolumn{7}{|c|}{ Academic achievement } \\
\hline Pre-test & 22 & 13,18 & 4,21 & \multirow{2}{*}{1,67} & \multirow{2}{*}{, 11} & \multirow{2}{*}{, 11} \\
\hline Post-test & 22 & 15,54 & 4,38 & & & \\
\hline \multicolumn{7}{|c|}{ Basic process skills } \\
\hline Pre-test & 22 & 14,09 & 3,96 & \multirow{2}{*}{,317 } & \multirow{2}{*}{,755 } & \multirow{2}{*}{, 004} \\
\hline Post-test & 22 & 14,54 & 4,52 & & & \\
\hline \multicolumn{7}{|c|}{ Attitudes towards science } \\
\hline Pre-test & 22 & 52,72 & 4,90 & \multirow{2}{*}{, 552} & \multirow{2}{*}{, 587} & \multirow{2}{*}{, 01} \\
\hline Post-test & 22 & 52,09 & 3,08 & & & \\
\hline
\end{tabular}

The results of the paired samples t-test conducted on the academic achievement, basic process skills and attitudes towards science pretest and posttest scores of control group are presented in Table 5. It was found the medium-big effect in academic achievement; the less than small effect in basic process skill and the small effect in attitudes towards science.

Table 6.

The Experimental Group Paired Samples t-Test Results

\begin{tabular}{|c|c|c|c|c|c|c|}
\hline Test & $\mathrm{n}$ & $\overline{\mathrm{x}}$ & sd & $\mathrm{t}$ & $\mathrm{p}^{*}$ & $\eta 2$ \\
\hline \multicolumn{7}{|c|}{ Academic achievement } \\
\hline Pre-test & 25 & 12,40 & 4,60 & \multirow{2}{*}{2,867} & \multirow{2}{*}{,008 } & \multirow{2}{*}{,24 } \\
\hline Post-test & 25 & 16,68 & 5,92 & & & \\
\hline \multicolumn{7}{|c|}{ Basic process skills } \\
\hline Pre-test & 25 & 13,96 & 4,59 & \multirow{2}{*}{1,66} & \multirow{2}{*}{, 11} & \multirow{2}{*}{,09 } \\
\hline Post-test & 25 & 16,44 & 5,02 & & & \\
\hline \multicolumn{7}{|c|}{ Attitudes towards science } \\
\hline Pre-test & 25 & 53,20 & 4,04 & \multirow{2}{*}{5,368} & \multirow{2}{*}{, $000 *$} & \multirow{2}{*}{, 53} \\
\hline Post-test & 25 & 60,36 & 4,66 & & & \\
\hline
\end{tabular}


The results of the paired samples t-test conducted on the academic achievement, basic process skills and attitudes towards science pretest and posttest scores of experimental group are presented in Table 6. It was found the significant effect in academic achievement and attitudes towards science, the medium-big effect in basic process skill.

\section{Conclusion and Discussion}

The comparison of the pretest mean scores of the students in the experimental and control groups revealed that there was no significant difference between the groups. This finding demonstrated that before the study, the prior knowledge of the students in both groups on 'Let's Learn about Matter' unit were similar before the study. Following the instruction, the comparison of the post-test mean scores of the experimental and control groups revealed a difference between the groups based on academic achievement favoring the experimental group. It was determined that the difference was not significant but it was found small effect size based on partial eta square. Thus, it could be suggested that the argumentation-based science instruction could play a role in the improvement of the academic achievements of the students. However, the contribution could be significant when the duration of the instruction could be expanded. In previous studies, Cangöz (2020) reported that argument-based virtual laboratory applications positively affected the academic achievement of the students, Erdogan (2010) found that the academic success of the experimental group students when argumentation-based instruction was conducted in the primary school 5th grade 'Earth, Sun and Moon unit' was higher when compared to the control group that was instructed with the conventional method. Uluay (2012) concluded that the argumentation-based instruction effectively improved academic achievements of the students in the 7th grade Science and Technology course 'Force and Motion' unit. In a study conducted by Öğreten and Uluçınar (2014), where the effect of argumentation-based activities on the academic achievement of 4th grade students and the development of discussion skills was investigated, it was observed that there was a significant difference between post-instruction academic achievements favoring the experimental group where argumentation-based activities were conducted. Yeşildağ-Hasançebi and Günel (2013) concluded that the application of argumentation-based science learning (ABSL) approach in the 'Structure and Properties of the Matter' unit contributed to the academic achievement of the students. Furthermore, other studies also reported the impact of argumentation-based instruction on student academic achievement (Akbaş, Şahin \& Meral, 2019; Aslan, 2019; Driver Newton \& Osborne, 2000; Noviyanti, Mukti, Yuliskurniawati Mahanal \& Zubaidah, 2019; Yalçın, 2019). In addition, Nasimudheen and Musthafa (2015) indicated that argumentation is effective in enhancing achievement in science,

The analysis of the scientific process skills pre-test data demonstrated that there was no significant difference between the experimental and control groups. Thus, it could be suggested that the scientific process skill levels of the experimental and control groups were similar before the study. In addition, the analysis of the posttest scores showed that there was no significant difference between control and experimental groups. However, it was found small-medium effect size based on partial eta square among the groups. Thus, the argumentation-based instruction of the science course was effective on the development of the scientific process skills of the students. In the literature, there are studies that investigated the effects of argumentationbased instruction on the development of scientific process skills of the students. In a study by Tatlisu (2020), it was concluded that the argumentation method positively affected scientific process skills of the students. Similarly, Ural and Gençoğlan (2020) reported that the argumentation-based approach in science instruction had a significant effect on students' scientific process skills. The findings of the study conducted by Öç (2019) demonstrated that argumentation-based science laboratory applications improved the scientific process skills of pre-service teachers. Richmond and Striley (1996) also reported that conducted discussions led 
The Impact of Argumentation-Based Instruction on Academic Achievements and Scientific Process Skills of Primary School Students and Their Attitudes Towards the Science Course

to positive changes in the scientific research skills of the students. In another study done by Su (2020) showed that argumentation based study with concept maps promoting students' critical thinking and improving self-confidence of science process skills. However, in a study by Gümrah (2013), it was reported that the scientific discussion method did not lead to a significant difference between the scientific process skills of the experimental and control group students. The review of the findings reported in a study by Gültepe (2011) demonstrated that scientific discussion-based instruction adopted in certain curriculum units made a significant difference in the development of scientific process skills of high school juniors; however, it did not have a similar effect in the "Reaction Speed" unit. Since the development of scientific process skills at the primary school level would be the cornerstone of advanced grades, it is important to improve these skills with argumentation-based activities.

The analysis of the pre-test attitude scores of the experimental and control groups towards the science course demonstrated that there was no significant difference between the two groups before the application; however, a significant difference was determined after the application favoring the experimental group. Thus, argumentation-based instruction contributed to student attitudes towards the science course. Similarly, Oğuz Çakır (2011) reported that discussion-based instruction helped 6th grade students develop a positive attitude towards the science course. Çelik (2010) also determined that the scientific discussion-based instruction improved student attitudes towards the chemistry course during the instruction of 9th grade "Structure of Matter" unit and 10th grade "Gases" unit. In addition, in a study conducted by Erdoğan (2010) on 5th grade students, a significant difference that favored the experimental group was reported between the attitudes towards science scores of the experimental group where argumentation-based instruction was conducted and the control group where the courses were instructed with the conventional method. Other study findings were also consistent with the above-mentioned results (Osborne, Simon, \& Collins, 2003; Walker et al., 2012; Yüksel, 2019).

An overview of the current study findings would reveal that argumentation-based instruction contributed to academic achievements, scientific process skills of 4th grade students and their attitudes towards the science course. However, there is a need for studies to be conducted with different samples and with more students. In addition, it is recommended to conduct longer studies that will continue for more than five weeks in future studies.

\section{Recommendations}

The following are recommended based on the study findings:

1. The study sample was limited. To generalize the effects of argumentation-based instruction and to understand its effects better, further studies could be conducted with larger samples.

2. The study was conducted only during the instruction of the "Let's Learn about Matter" unit in the science course. Argumentation could be analyzed during the instruction of other science topics or its effects on various courses could be investigated.

3. The study was conducted during five weeks, where the instructions were conducted three hours a week. Future research could be conducted during longer periods to re-analyze the present study findings.

4. Various material, worksheets and activities that would be interesting for the students could be developed to further include the argumentation method in school instruction.

5. In the study, the impact of the method on academic achievements, scientific process skills and attitudes towards science course were investigated. Instead, the effects of the 
argumentation-based instruction method on various areas such as social skills could be investigated in future studies.

6. The study only included primary school 4th grade students. Argumentation-based instruction could also be investigated in 3rd grade level, where students encounter science for the first time.

7. Future studies could be conducted on the impact of the skills acquired by the students in argumentation-based instruction on daily life.

8. Teachers could further include argumentation-based classroom activities and scientific discussions in primary schools for students to comprehend the instruction method better.

\section{References}

Açıkgöz, K. Ü. (2002). Aktif ögrrenme [Active learning] (6 ${ }^{\text {th }}$ ed.). İzmir: Eğitim Dünyası Publishing.

Akbaş, Y., Şahin, İ. F.., \& Meral, E. (2019). Implementing argumentation-based science learning approach in social studies: Academic Achievement and Students'. Views. Review of International Geographical Education Online (RIGEO), 9(1), 209-245. doi: 10.33403/rigeo.529139.

Akkus, R., Gunel, M., \& Hand, B. (2007). Comparing an inquiry-based approach known as the science writing heuristic to traditional science teaching practices: are there differences? International Journal of Science Education, 1, 1-21. doi: 10.1080/09500690601075629.

Aldağ, H. (2006). Toulmin tartışma modeli [The Toulmın model of Argumentation]. Çukurova University Journal of Social Sciences Institute, 15(1), 13-34.

Anagün, Ş. S., Kılıç, Z., Atalay, N., \& Yaşar, S. (2015). Are classroom teacher candidates ready to perform science curriculum?. Turkish Studies-International Periodical for the Languages, Literature and History of Turkish or Turkic, 127-148. doi: http://dx.doi.org/10.7827/TurkishStudies.8611

Arı, M. (2016). Effectiveness of argumentation based learning on seventh grade students' awareness about demarcation of science. (Unpublished master's thesis). İstanbul University, Institute of Education Science, İstanbul.

Aslan, S. (2010). The effect of argumentation-oriented teaching approach on the improvement of their top scientific process and critical thinking among high school 10. class students. (Unpublished doctoral dissertation). Gazi University, Ankara.

Aslan, S. (2019). The impact of argumentation-based teaching and scenario-based learning method on the students' academic achievement. Journal of Baltic Science Education, 18(2), 171-183. doi: 10.33225/jbse/19.18.171.

Ayas A. (1995). Fen bilimlerinde program geliştirme ve uygulama teknikleri üzerine bir çalışma: İki çağdaş yaklaşımın değerlendirilmesi [A study on curriculum development and implementation techniques in science: Evaluation of two contemporary approaches]. Hacettepe University Journal of Education, 11, 149-155.

Burke, K. A., Greenbowe, T. J., \& Hand, B. M. (2005). Excerpts from 'The process of using inquiry and the science writing heuristic', Prepared for the Middle Atlantic Discovery Chemistry Program. Bethlehem: Moravian College.

Canöz, G. M. (2020). Investigate the effect of argumentation based virtual laboratory activities on academic achivement, argumentation levels and entrepreneurship skills. (Unpublished master's thesis). Çukurova Universtiy, Adana.

Ceylan, Ç. (2010). Implementing the science writing heuristic (SWH) approach in science laboratory activities.. (Unpublished master's thesis). Gazi University, Ankara.

Cin, M. (2013). Effects of concept cartoon activities based-argumentation method on students' conceptual understanding levels and scientific process skills. (Unpublished master's thesis). Dokuz Eylül University, İzmir.

Cresswell, J. W. (2003). Research Design. California: Sage Publication. 
The Impact of Argumentation-Based Instruction on Academic Achievements and Scientific Process Skills of Primary School Students and Their Attitudes Towards the Science Course

Çepni, S. (2011). Araştırma ve proje çalışmalarına giriş [Introduction of research and project]. Trabzon: Celepler Publishing.

Demircioğlu, T. (2011). To investigate the effect of argument-driven inquiry on pre-service science teachers' laboratory instruction. (Unpublished master's thesis). Çukurova University, Institute of Social Science, Adana.

Driver, R., Newton, P., \& Osborne, J. (2000). Establishing the norms of scientific argumentation in classrooms. Science Education, 84(3), 287-312.

Erdoğan, S. (2010). Investigate the effects of teaching earth, sun and moon topics through argumentation on the success, attitude and argumentation skills of $5^{\text {th }}$ grade students. (Unpublished master's thesis). Uşak Univeristy. Institute of Social Science, Uşak.

Erduran, S., Simon, S. \& Osborne, J. (2004). Tapping into argumentation: Developments in the application of Toulmin's argument pattern for studying science discourse. Science Education, 88(6), 915-933. doi: 10.1002/sce.20012

Eryılmaz, A. (2002). Effects of conceptual assignments and conceptual change discussions on students' misconceptions and achievement regarding force and motion. Journal of Research in Science Teaching, 39, 1001-1015. doi: 10.1002/tea.10054

Geban, Ö., Ertepınar, H., Yılmaz, G., Atlan, A. \& Şahpaz, Ö. (1994). Bilgisayar destekli eğitimin öğrencilerin fen bilgisi başarılarına ve fen bilgisi ilgilerine etkisi [The effect of computer-assisted education on students' science achievement and science interests]. $I$. National Science Education Symposium. Dokuz Eylül University, Buca Education Faculty, İzmir.

Gencel, İ.E., \& Ilıman, M. (2019). A case study on argumentation based teaching. International Journal of Curriculum and Instructional Studies 9(1), 53-72. doi: 10.31704/ijocis.2019.003.

Gençoğlan, D. M. (2017). The efects of argumentation based science learning (ABSL) approach based on authentic case studies on the success, attitude and scientific process skills of 8 th grade students in the acids and bases lesson. (Unpublished master's thesis). Kahramanmaraş Sütçü İmam University, Institute of Science, Kahramanmaraş.

Gültepe, N. (2011). Effect of argumentation based instruction on improvement of high school student's science process skills and critical thinking ability. (Unpublished doctoral dissertation). Gazi University, Institute of Education Science, Ankara.

Gümrah, A. (2013). The effects of scientific argumentation on secondary students' conceptual understanding of chemical changes, nature of science views, science process, communication and argument skills. (Unpublished doctoral dissertation). Marmara University, Institute of Education Science, İstanbul.

Hacioğlu, Y. (2011). Investigating the effect of scientific argumentation based case studies on the concept learning and reading comprehension skills of 8-grade primary school students. (Unpublished master's thesis). Marmara University, İstanbul.

Hand, B., Shelley, M. C, Laugerman, M., Fostvedt, L., \& Therrien, W. (2018). Improving critical thinking growth for disadvantaged groups within elementary school science: A randomized controlled trial using the Science Writing Heuristic approach. Science Education, 102(4), 693-710. doi: 10.1002/sce.21341

Hand, B., Wallace, C. W., \& Yang, E. M. (2007). Using a science writing heuristic to enhance learning outcomes from laboratory activities in seventh-grade science: quantitative and qualitative aspects. International Journal of Science Education, 26(2), 131-149. doi: 10.1080/0950069032000070252.

Hanegan, N. L., Price, L., \& Peterson, J. (2008). Disconnections between teacher expectations and student confidence in bioethics. Science Education, 17, 921-940. doi: $10.1007 / \mathrm{s} 11191-007-9122-6$ 
Irish, T. E. (2012). Argumentation and equity in inquiry-based science instruction: reasoning patterns of teachers and students. (Unpublished doctoral dissertation). Oregon State University.

Karasar, N. (1999). Bilimsel araştırma yöntemleri [Scientific research methods]. Ankara: Nobel Publishing.

Kaya, O. N., \& Kıliç, Z. (2008). Argumentative discourse for the effective teaching of science. Ahi Evran University Journal of Kirşehir Education Faculty, 9(3), 89-100.

Keys, C. W., Hand, B., Prain, V., \& Collins, S. (1999). Using the science writing heuristic as a tool for learning from laboratory investigations in secondary science. Journal of Research in Science Teaching, 36(10), 1065-1084.

Kıngir, S. (2011). Using The Science writing heuristic approach to promote student understanding in chemical changes and mixtures. (Unpublished doctoral dissertation). Middle East Technical University, Ankara.

Köseoğlu, F., Tümay, H., \& Budak, E. (2008). Paradigm changes about nature of science and new teaching aproaches. Gazi University Journal of Gazi Educational Faculty, 28(2), 221-237.

Küçükaydın, M. A. (2019). Eighth Grade Students' Opinions on the Socioscientific Issue and Their Argument Structure. Elementary Education Online, 18(1), 175-189, doi: 10.17051/ilkonline.2019.527195.

Küçükyılmaz, E. A. (2014). Fen bilimleri dersi öğretim programı [Curriculum of science]. Ş. S. Anagün ve N. Duban (Eds.). Fen bilimleri ögretimi [Teaching of science] in (p. 59-86). Ankara: An1 Publishing.

Mallı, S. (2019). A descriptive analysis of academic studies on argumentation in science education in Turkey within the last ten years. (Unpublished master's thesis). Dokuz Eylül University, İzmir.

Ministry of National Education-MoNE (2013). İlkögrretim kurumları fen bilimleri dersi öğretim programı [Curriculum of science in primary school]. Ankara: Ministry of National Education.

Ministry of National Education-MoNE (2018). Illköğretim kurumları fen bilimleri dersi öğretim programı [Curriculum of science in primary school]. Ankara: Ministry of National Education.

Memis, E. K. (2017). Türkiye'de argümantasyon konusunda gerçeklestirilen tezlerin analizi: Bir meta-sentez çalışması [Analysis of theses on argumentation in Turkey: A MetaSynthesis Study]. Cumhuriyet International Journal of Education, 6(1), 47-65. doi: 10.30703/cije.32136.

Memiş, E. K. (2014). Elementary Students' ideas about on implementation of argumentation based science-learning approach. Kastamonu Education Journal, 22(2), 400-418.

Nasimudheen, M., \& Musthafa, M. N. M. A. (2015). Effectiveness of Argumentation based instruction on achievement in science of secondary school students. IOSR Journal of Humanities and Social Science, 20(10), 13-18. doi: 10.9790/0837-201051318.

Naylor, S., Keogh, B., \& Downing, B. (2007). Argumentation and primary science. Research in Science Education, 37(1), 17-39. doi: 10.1007 / s11165-005-9002-5.

Niaz, M., Aguilera, D., Maza, A., \& Liendo, G. (2002). Arguments, contradictions, resistances, and conceptual change in students' understanding of atomic structure. Science Education, 86(4), 505-525. doi: 10.1002/sce.10035.

Norris, S. P., \& Phillips, L. M. (2003). How literacy in its fundamental sense is central to scientific literacy. Science Education, 87, 224-240. doi: 10.1002/sce.10066.

Novianti, N.I., Mukti, W.R., Yuliskurniawati, I.D., Mahanal, S., \& Zubaidah, S. (2019). Students' scientific argumentation skills based on differences in academic ability. IOP Conf. Series: Journal of Physics: Conference Series, 1241, 1-8, doi: 10.1088/1742$6596 / 1241 / 1 / 012034$.

Oğuz Çakır, B. Z. (2011). The influence of argumentation based instruction on sixth grade students' attitudes toward science, conceptual understandings of physical and chemical 
The Impact of Argumentation-Based Instruction on Academic Achievements and Scientific Process Skills of Primary School Students and Their Attitudes Towards the Science Course

change topic and argumentativeness. (Unpublished master's thesis). Middle East Technical University, Institute of Education Science, Ankara.

Okumuş, S. (2012). The effects of argumentation model on student's achievement and understanding level on the unit of states of matter and heat. (Unpublished master's thesis). Karadeniz Technical University, Institute of Education Science, Trabzon.

Osborne, J. F. (2007). Science education for the twenty first century. Eurasia Journal of Mathematics, Science and Technology Education, 3(3), 173-184. doi: 10.12973/ejmste/75396.

Osborne, J., Simon, S., \& Collins, S. (2003). Attitudes towards science: A review of the literature and its implications. International Journal of Science Education, 25(9), 10491079. doi: 10.1080/0950069032000032199.

Öç, U. (2019). Scientific process skills of science lab applications based on argumentation, their effects on the attitude for laboratory and the creativity. (Unpublished master's thesis). Sivas Cumhuriyet University, Institute of Education Science, Sivas.

Öğreten, B., \& Uluçınar-Sağır, Ş. (2014). Argümantasyona dayalı fen öğretiminin etkililiğinin incelenmesi [Examining the effectiveness of argumentation-based science teaching]. Journal of Turkish Science Education,11(1), 75-100. doi: 10.12973/tused.10104a).

Özer, M. (2019). The Effect Of Argumentation Based Teaching In Science Education: MetaAnalysis Study. (Unpublished master's thesis). Sivas Cumhuriyet University, Sivas.

Özkara, D. (2011). Teaching pressure subject to eighth class students with activities based on scientific argumentation. (Unpublished master's thesis). Adiyaman University. Adiyaman.

Padilla, M., Cronin, L., \& Twiest, M. (1985). The development and validation of the test of basic process skills. Paper presented at the annual meeting of the National Association for Research in Science Teaching, French Lick, IN.

Puvirajah, A. (2007). Exploring the quality and credibility of students' argumentation: Teacher facilitated technology embedded scientific inquiry. Wayne State University. Detroid, Michigan. UNI.

Richmond, G., \& Striley, J. (1996). Making meaning in classrooms: Social processes in small-group discourse and scientific knowledge building. Journal of Research in Science Teaching, 33(8), 839-858.

Simon, S. (2008). Using Toulmin 'e argument pattern in the evaluation of argumentation in school science. International Journal of Research \& Method in Education, 31(3), 277289. doi: 10.1080/17437270802417176.

Simon, S., Erduran, S., \& Osborne, J. (2006). Learning to teach argumentation: Research and development in the science classroom. International Journal of Science Education, 28(2-3), 235-260. doi: 10.1080/09500690500336957.

$\mathrm{Su}, \mathrm{K}-\mathrm{D}$. (2020). An argumentation-based study with concept mapping approach in identifying students' scientific performance skills. Interdisciplinary Journal of Environmental and Science Education, 16(4), doi: https://doi.org/10.29333/ijese/8544

Şekerci, A. R. (2013). The effect of argumentation based instruction on student's argumentation skills and conceptual understanding in Chemistry laboratory. (Unpublished doctoral dissertation). Atatürk University, Erzurum.

Tatlısu, S. (2020). Fen bilimleri dersinde argümantasyon yöntemi kullanilmasının 7. sinif ögrencilerinin fen ögrenme becerisi ve bilimsel süreç becerileri üzerine etkisinin incelenmesi [Investigation of the effect of using argumentation method in science lesson on $7^{\text {th }}$ grade students' science learning skills and scientific process skills]. (Unpublished master's thesis). Akdeniz University, Antalya.

Toulmin, S. (1958). The uses of argument. Cambridge: Cambridge University Press. 
Tümay, H., \& Köseoğlu, F. (2011). Kimya öğretmen adaylarının argümantasyon odaklı öğretim konusunda anlayışlarının geliştirilmesi [Developing chemistry teacher candidates' understanding of argumentation-based teaching]. Turkish Science Education, 8(3), 105119.

Uluay, G. (2012). Investigation of the effect of scientific argumentation based teaching on student's success in teaching Primary School 7th grade Science and Technology course force and motion unit teaching. (Unpublished master's thesis). Kastamonu University, Institute of Science, Kastamonu.

Uluçınar Sağır, Ş. (2008). Investigation of effectiveness of argumentation theory based teaching in science courses (Unpublished doctoral dissertation). Gazi University, Institute of Education Science, Ankara.

Ural, E., \& Gençoğlan, D. M. (2020). The effect of argumentation-based science teaching approach on $8^{\text {th }}$ graders' learning in the subject of acids-bases, their attitudes towards science class and scientific process skills. Interdisciplinary Journal of Environmental and Science Education, 16(1). doi: 10.29333/ijese/6369.

Üstünkaya, I. \& Savran Gencer, A. (2012). İlköğretim 6. sınıf seviyesinde bilimsel tartışma (argumentation) odaklı etkinliklerle dolaşım sistemi konusunun öğretiminin akademik başarıya etkisi. X. National Education of Science and Mathematics Congress, Niğde University.

Venville, G. J.,\& Dawson, V. M. (2010). The impact of a classroom intervention on grade 10 students' argumentation skills, informal reasoning, and conceptual understanding of science. Journal of Research in Science Teaching,47(8), 952-977. doi: 10.1002/tea.20358.

Walker, J. P., Sampson, V., Grooms, J., Anderson, B., \& Zimmerman, C. O. (2012). Argumentdriven inquiry in undergraduate chemistry labs: The impact on students' conceptual understanding, argument skills, and attitudes toward science. Journal of College Science Teaching, 41(4), 74.

Yalçın Çelik, A. (2010). An analysis of the influences of the teaching approach based on scientific argumentation on high school students' conceptual understanding, attitudes, and willingness for argumentation and the quality of argumentation. (Unpublished master's thesis). Gazi University, Ankara.

Yalçın, G. A. (2019). The effect of argumentation based science learning approach on academic success and motivation of 9th grade students in a physics course. (Unpublished master's thesis). Gazi University, Ankara.

Yeh, K. H., \& She, H. C. (2010). On-line synchronous scientific argumentation learning: Nurturing students' argumentation ability and conceptual change in science context. Computers \& Education, 55(2), 586-602. doi: 10.1016/j.compedu.2010.02.020.

Yeşildağ Hasançebi, F., \& Günel, M. (2013). Effects of argumentation based inquiry approach on disadvantaged students' science achievement. Elementary Education Online, 12(4), $1056-1073$.

Y1ldırır, H. E. (2013). The evaluation of learning environment based argumentation in classroom: A case study involving experienced chemistry teachers and prospective chemistry teachers. (Unpublished doctoral dissertation). Balıkesir University, Institute of Science, Balikesir.

Yüksel, Y. (2019). The effect of argumentation based biology instruction on achievement, attitude and critical thinking skills. (Unpublished doctoral dissertation). Gazi University, Institute of Education Science, Ankara

Zohar, A., \& Nemet, F. (2002). Fostering students' knowledge and argumentation skills through dilemmas in human genetics. Journal of Research in Science Teaching, 39(1), 35-62. doi: 10.1002/tea.10008. 